\title{
Piliostigma thonningii leaves as dry season feed supplement for West African dwarf goats
}

Jemiseye, F. O., Akinlade, J. A., Ogunwole, O. A. and Adedeji, B. S. Agricultural Biochemistry and Nutrition, Department of Animal Science, University of Ibadan Department of Animal Production and Health, Ladoke Akintola University of Technology, Ogbomoso, Nigeria Corresponding author: jemiseyefo@gmail.com; +2348037064917

\section{Abstract}

A persistent issue with ruminant production during the dry season in the tropics is scarcity of forages. Producers are faced with the search for alternative feed supplements to address this issue without compromising productivity. Acceptability of Piliostigma thonningii as dry season feed supplement to West African dwarf (WAD) goat was investigated in this study. The WAD goats $(n=15)$ were divided into three treatments of five goats each in a completely randomized design. The animals were fed with Panicum maximum without supplementation at 100\% (T1), 90\% Panicum maximum $+10 \%$ Piliostigma thonningii (T2) and $80 \%$ Panicum maximum $+20 \%$ Piliostigma thonningii (T3). Fresh water was also made available throughout the trial that lasted six weeks. Chemical analysis of the forages was observed while feed intake, weight gain and nutrient digestibility were monitored. Results showed that Piliostigma thonningii had a higher (15.25\%) crude protein and lower (57.38\%) neutral detergent fibre contents than the grass. Both had comparable energy values. Piliostigma thonningii had relatively high mineral contents while the anti-nutrient contents of phytate and oxalate were relatively low. Although the crude protein intake increased with increasing levels of supplementation, the total dry matter intake was not favoured beyond $10 \%$ level of Piliostigma thonningii level. It can be concluded that there was no advantage in feeding West African dwarf goat Piliostigma thonningii beyond 10\% level.

Keywords: Piliostigma thonningii, West African dwarf goat, Panicum maximum

\section{Introduction}

Good genetic quality coupled with adequate nutrition is among factors that contribute to the success of any livestock industry. This success could be achieved when adequate and nutritionally balanced diets are provided for the animals. Ruminant animals depend solely on roughages to survive, because of their stomach compartment which are able to digest fibrous feeds better than concentrates. Since they live entirely on roughages, there is a need to provide the animals with adequate feed that will be enough for body maintenance and productivity so as to achieve better performance and to maximize profit.

Climate influences both distribution of animals and the chemical composition and nutritive_value of pasture plants (Parker and Blowey, 1976). During the rainy season, ruminant animals are able to obtain adequate nutrients from forages because of availability and often graze selectively and consume most succulent and nutritious forages. But due to unavailability or insufficient water supply during the dry season, grasses dry off and of course the nutrient requirement of these animals is not met. It is known from studies that grasses may contain up to $12 \%$ crude protein during the rainy season which is adequate for effective rumen microbial activity, but this is not always so in the dry season. During dry season, the crude protein contents of grasses can be very low (Abdelrahman et al., 1998. As a result of this, the available grasses during the dry 


\section{Piliostigma thonningii leaves as dry season feed supplement for West African dwarf goats}

season have to be supplemented so as to make up for the crude protein and other nutrients needed by the animal for effective rumen activity and microbial degradation. Therefore, for ruminant production to be economically viable and profitable, goat husbandry during the period of drought depends on inexpensive and readily available feed resources (Akingbade et al., 2006). Piliostigma thonningii, is a leguminous plant whose leaves are browsed by ruminant animals during the dry season, is a shrub tree of about $6 \mathrm{~m}$ high, often of crooked growth with dark brown to black fissured bark. Leaves digitately 11-12 nerved, the central nerve prolonged as a point into the notch between the lobes of the leaf, leaves 7.5 to $15 \mathrm{~cm}$ long, leathery, very strongly reticulate. In racemes alternately leaf opposed and auxilliary along each branch and borne somewhat horizontally. It is very similar to Piliostigma reticulatum in its pod formation and utilization. Piliostigma thonningii, is also known as Camel's foot, Monkey bread, Rhodesian bauhinia, it is locally known as "abefe" "Kaloo" and "Okpoatu" in Yoruba, Hausa and Igbo respectively in Nigeria (Jimoh and Oladeji, 2005).

Guinea grass originated in Africa and widely distributed in South Africa, is a pasture plant of tropical origin whose distribution also covers a wide range of ecological zones in Nigeria (Adegbola and Onayinka, 1996). Panicum maximum is a perennial, tufted grass with a short creeping rhizome, its stems can reach a height of up to $2 \mathrm{~m}$. It remains green until late into winter, its leaf blades are up to $35 \mathrm{~mm}$ wide and taper to a long fine point (Gibbs et al., 1991). Panicum maximum prefers fertile soil and is well adapted to a wide variety of conditions, it is often seen along rivers and frequently found in open woodland, it is considered to be the most valuable fodder plant in the area where it is distributed, it is especially used to make good quality hay.
Goats are used for meat and form an important source of earning for the farmers. By the export of their skin and their use in the leather industries, goats also contribute immensely to the total foreign exchange earnings of the country. (Gbolagunle and Mshelbwala, 1991). Production of goat requires low investment in labour and capital. The keeping of goats in any community is related to the value attached to their production. Goats are mainly kept for meat (Williamson and Payne, 1978). In addition, goats play an important role in the welfare of the smallholder arable farmer in Nigeria through the income generated when sold. There is global concern about alleviating poverty and improving the welfare of the rural poor. The sale of goats could improve the welfare of farmers, particularly women, most of whom own goats and who, along with children, are entrusted with the care of small ruminants. Traditional methods of keeping goats in the wet season are tethering or free-range grazing on enclosed natural pasture. While this restriction of movement may prevent crop damage, it induces feed stress.

The introduction of herbaceous legumes into enclosed fallow land is attractive to farmers because it alleviates the feed constraint in the dry season. At the same time, it fixes nitrogen from the atmosphere, helping to restore or increase soil fertility for subsequent cropping. There is, however, dearth of information on WAD Goat offtake in the sub-humid zone (SHZ) of Nigeria. This study was designed to determine the chemical composition of Piliostigma thonningii and assess its acceptability and digestibility as dry season feed supplement in West African dwarf goat.

\section{Materials and methods \\ Location of experiment}

The experiment was conducted at the Cattle, Sheep and Goat unit of Teaching and Research Farm, Ladoke Akintola 


\section{Jemiseye, Akinlade, Ogunwole and Adedej}

University of Technology, Ogbomoso located in the derived savanna zone of latitude $8^{0} 26^{\prime} \mathrm{N}$ and longitude $4^{0} 49^{\prime} \mathrm{E}$ of Nigeria with mean annual rainfall of $1247 \mathrm{~mm}$ and mean temperature of about $27^{\circ} \mathrm{C}$.

Experimental animals and their management

A total number of 15 West African Dwarf goat of about two years old were purchased from local markets. Before the arrival of the goats, the pens were prepared, cleaned, disinfected and the floor was covered with wood shavings. Other equipment used, like buckets, feeding troughs, drinking troughs and brooms was also washed and cleaned thoroughly. Animals were kept in separate abodes. They were treated against ecto and endo parasite using Ivomectin, before the commencement of the experiment. Animals were allowed an adjustment period of two weeks after the animals has been purchased.

\section{Experimental layout/feed intake}

The WAD goats $(n=15)$ were divided into three treatments of five goats each in a completely randomized design. Each Goat served as a replicate. The animals were fed with Panicum maximum without supplementation at $100 \%$ (T1), 90\% Panicum maximum $+10 \%$ Piliostigma thonningii (T2) and 80\% Panicum maximum $+20 \%$ Piliostigma thonningii (T3). Daily dry matter requirement was constituted as $3 \%$ body weight of individual animals. Fresh water was also made available throughout the trial that lasted six weeks. Chemical analysis of the forages was observed while feed intake, weight gain and nutrient digestibility were monitored.

\section{Forage-harvest and methods offeeding}

Fresh Panicum maximum was harvested from the Teaching and Research Farm pasture plot of the University, and chopped into small pieces of about $5 \mathrm{~cm}$ length. Piliostigma thonningii leaves were harvested from within the premises of the University farm. Piliostigma thonningii was fed in wilted form. Wilted was defined as having allowed the leaves to stay for 24hours before being used for feeding. Both Panicum maximum and Piliostigma thonningii were offered to the animals in same feed through.

\section{Data collection}

Feed intake was estimated by the differences in measured feed provided and the left over weighed the following morning before another fresh feed was offered.

\section{Weight change}

Before the commencement of the experiment, the initial weight of the animals for each level of treatment was taken, thereafter, the animals were also weighed at the end of each week, the final body weight of each experimental animal was taken at the end of the experiment.

\section{Digestibility study}

One buck from the treatments was put in the metabolic cages. The cage was equipped with facilities that allowed for separate collections of urine and faeces. Collection of faeces was done through the net under metabolic cage. Total daily faecal output for each goat were measured and mixed, subsample of faeces were oven dried for fortyeight hours at a temperature of $60^{\circ} \mathrm{C}$ to determine the dry matter content.

\section{Laboratory analysis}

Samples of Panicum maximum, Piliostigma thonningii leaves and faecal sample were analysed for Ash, Crude protein, NDF, ADF and ADL contents (AOAC, 1990).

\section{Experimental design and statistical} analysis

The experiment was completely randomized with each animal serving as a replicate. Data was analysed using GLM of SAS (2003) and means were separated using Duncan's multiple range test at a probability level of $5 \%$. 


\section{Results and discussion}

The chemical composition of the forage plants used in this study is shown in Table 1. The GE (Kcal/g) of Panicum maximum and Piliostigma thonningii were 3.89 and 3.56, respectively while NDF (69.59), ADF (54.26) and ADL (18.38) were relatively higher in Panicum maximum compared to 57.38, 26.72 and 11.98, respectively in Piliostigma thonningii. Crude protein however in Piliostigma thonningii (15.25) was relatively higher than in Panicum maximum (7.67). The crude protein value recorded in this study for $P$. thonningii was higher than $9.88 \%$ reported by Van Rensbury (1968). The difference in the values could be as a result of difference in localities. However, the values obtained for Panicum maximum from this study were comparable to those reported by Jiwuba et al. (2016) but lower than those reported by Etela and Suoware et al. (2012).

Table 1: Gross energy and chemical composition of forage plants

\begin{tabular}{lll}
\hline Parameters & Panicum maximum & Piliostigma thonningii \\
\hline CP & 7.67 & 15.25 \\
NDF & 69.59 & 57.38 \\
ADF & 54.26 & 26.72 \\
ADL & 18.38 & 11.98 \\
GE $(\mathrm{Kcal} / \mathrm{g})$ & 3.887 & 3.567 \\
\hline
\end{tabular}

$\mathrm{CP}=$ Crude protein, $\mathrm{NDF}=$ Neutral detergent fibre, $\mathrm{ADF}=$ Acid detergent fibre,

$\mathrm{ADL}=$ Acid detergent lignin, $\mathrm{GE}=$ Gross energy

Mineral compositions of the forage plants are shown in Table 2. The values of $\mathrm{K}, \mathrm{Mg}$, $\mathrm{P}, \mathrm{Fe}$, and $\mathrm{Zn}$ in $P$. maximum are relatively higher than that of $P$. thonningii, while higher values of $\mathrm{Ca}$ and $\mathrm{Cu}$ were observed in $P$. thonningii. Potassium contents of the forages though in minute proportion did not have any detrimental effect on the animal because all plants contain potassium which help in metabolism (Merck, 2008). Deficiency of calcium is attributed to reduced milk production and milk fever while. deficiency of magnesium is associated with hypomagnesemictetany (grass tetany). Similarly, for phosphorus, deficiency results in slowed growth, unthrifty appearance and occasionally a depraved appetite while Iron deficiency is seldom seen in mature grazing goat as it is common to young goat. Parakeratosis, stiffness of joints, smaller testicles and lowered libido are symptoms of zinc deficiencies. These conditions however were not observed in any of the experimental animals. This could mean that the forages met the requirement of these animals for the monitored nutrients. Also, goats do have marginal ability to compensate for low magnesium by decreasing the amount of magnesium they excrete (Merck, 2008).

Table 2: Mineral composition of the forage plants

\begin{tabular}{lcc}
\hline Parameters & Panicum maximum & Piliostigma thonningii \\
\hline $\mathrm{K}(\%)$ & 0.94 & 0.83 \\
$\mathrm{Ca}(\%)$ & 0.79 & 0.82 \\
$\mathrm{Mg}(\%)$ & 0.65 & 0.61 \\
$\mathrm{P}(\%)$ & 0.73 & 0.39 \\
$\mathrm{Fe}(\mathrm{mg} / \mathrm{kg})$ & 205.20 & 139.70 \\
$\mathrm{Zn}(\mathrm{mg} / \mathrm{kg})$ & 31.30 & 29.10 \\
$\mathrm{Cu}(\mathrm{mg} / \mathrm{kg})$ & 6.50 & 6.80 \\
\hline $\mathrm{K}=$ Potassium, $\mathrm{Ca}=$ Calcium, $\mathrm{Mg}=$ Magnesium, $\mathrm{P}=$ Phosphorus, $\mathrm{Fe}=$ Iron, $\mathrm{Zn}=$ Zinc, $\mathrm{Cu}=$ Copper &
\end{tabular}




\section{Jemiseye, Akinlade, Ogunwole and Adedej}

The composition of selected anti-nutrients in Panicum maximum and Piliostigma thonningii are shown in Figure 1. Phyate, oxalate and tannin concentrations (1.26, 1.37 and 0.078 , respectively) in Panicum maximum were relatively higher than 1.18 , 1.26 and 0.069 , respectively in Piliostigma thonningii. The nutritional importance of a given food or vegetable depends on the nutrients or anti-nutritional constituents (Aletor and Omodara, 1994). Availability of nutrients is mostly affected by the presence of antinutrients. These factors make nutrients unavailable by forming complexes with bivalent ions like $\mathrm{Ca} 2+, \mathrm{Zn} 2+, \mathrm{Mg} 2+$ and $\mathrm{Fe} 2+$ (Aletor and Omodara, 1994). Oxalate is a natural occurring substance found in plants animal and human which its consumption in large amount can cause disease even death (Prakash, 1993). Osagie and Eka (1998) observed that phytic and oxalic acids are generally present in plants and specifically affect the availability of minerals. Phytic acid is a known factor that makes phosphorus unavailable in feedstuff. Even when there is a relatively abundant level of phosphorus in a feed material, higher level of phytate is a dictate that a bunch of the phosphorus will be locked up and made unavailable for the use of the consuming animal. Tannins on the other hand have both negative and positive effects on nutritive value. Condensed tannins adversely affect palatability and animal performance. Tannins-protein complexes decrease rumen ammonia concentrations thus inhibiting fermentation of structural carbohydrates and may also render protein unavailable for digestion in the small intestine, increase faecal nitrogen and consequently lower nitrogen retention. Tannins beneficial roles however, includes prevention of protein degradation in the rumen, thereby increasing bypass proteins for hindgut protein digestion, and also safeguarding against occurrence of bloat due to their ability to precipitate protein (Akingbade $e t$ al., 2006). Tannin concentration reported in this work was below the range of 1.43$1.53 \%$ reported by Khan et al. (2015) in wild edible forages consumed by ruminants. Consumption of higher level of tannins has been reported to be hazardous to health (Oakenfull and Sidhu, 1990) while protein digestibility is greatly affected by tannins due to formation of complexes (Sathe et al., 1984).

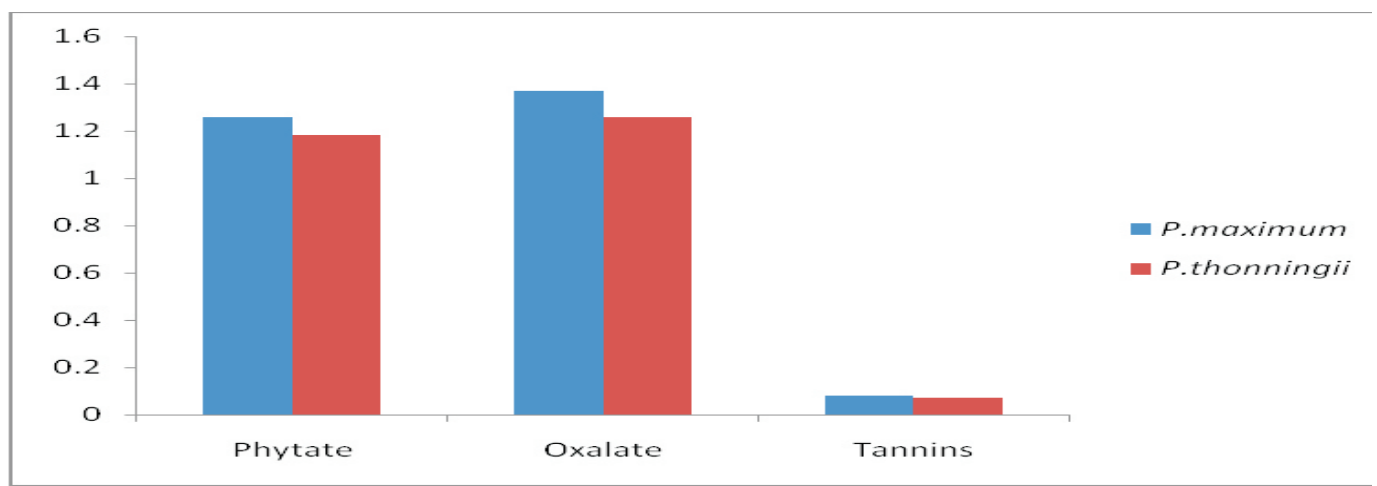

Figure 1: Composition of selected anti-nutrients in Panicum maximum and Piliostigma thonningii 
Weight gain and voluntary feed intake of WAD goats fed Panicum maximum supplemented with Piliostigma thonningii is shown in Table 3. Total dry matter intake was significantly higher $(\mathrm{P}<0.05)$ in WAD goats on T2 (82.34) compared to 73.20 and 65.50 in the control and T3, respectively. The higher dry matter intake observed in T2 compared with the non-supplemented group may indicate that $10 \%$ supplemental Piliostigma thonningii made the forage more palatable to the WAD goats. Further increment in the supplement however resulted in lower intake of the forage. There have been reports of lower intake of feed stuff as a result of phytochemicals present in them especially due to the bitter nature of saponin. The reduction in dry matter intake due to T3 may be as a result of other antinutrients present in Piliostigma thonningii that were not assayed for in this study. The NDF and ADF were similar across treatments indicating that both forages have similar fibre constituents. Crude protein in T2 and T3 were similar $(\mathrm{P}>0.05)$ but significantly different $(\mathrm{P}<0.05)$ from $\mathrm{T} 1$. The increment observed in $\mathrm{CP}$ of $\mathrm{T} 2$ and $\mathrm{T} 3$ could be linked to the relatively higher CP level in Piliostigma thonningii when compared to P. maxima (Table 1). Weight gain was however higher in $\mathrm{T} 2$ compared to $\mathrm{T} 1$ and $\mathrm{T} 3$. The observation in weight gain was probably due to the dry matter intake of the individual treatments as goats on T2 with higher weight gain had the highest DM intake while those on $\mathrm{T} 3$ had the lowest.

Table 3: Weight gain and voluntary feed intake by WAD goats fed basal diet of Panicum maximum supplemented with Piliostigma thonningii

\begin{tabular}{lllll}
\hline & \multicolumn{3}{c}{ Level of Piliostigma thonningii supplementation } & \\
\cline { 2 - 4 } & 0 & 10 & 20 & SEM \\
Parameters & & $82.34^{\mathrm{a}}$ & $65.50^{\mathrm{c}}$ & 4.60 \\
\hline Total Dry matter intake (g/day) & $73.20^{\mathrm{b}}$ & 54.60 & 56.83 & 2.21 \\
NDF intake (g/day) & 50.73 & 38.56 & 38.32 & 2.81 \\
ADF intake (g/day) & 39.71 & $8.01^{\mathrm{a}}$ & $9.01^{\mathrm{a}}$ & 3.63 \\
Crude protein intake (g/day) & $4.34^{\mathrm{a}}$ & $23.74^{\mathrm{a}}$ & $11.12^{\mathrm{c}}$ & 4.10 \\
Weight gain g/h/day & $7.22^{\mathrm{b}}$ & &
\end{tabular}

Nutrient digestibility of $P$. maxima supplemented with $P$ thonningii is shown in Table 4. The digestibility value of crude protein, NDF and ADF increased with increasing level of supplemental Piliostigma thonningii leaves. Increase in digestibility of ADF is a measure of the plant components in forages that are the least digestible by livestock, including cellulose and lignin while NDF measures the fraction of fibre that are easily degradable. As forage ADF increases it is expected that digestibility decreases. Since P. maxima is high in ADF, it was expected that digestibility would be low. Contrary to expectation however, there was improvement in ADF digestibility of the forages with increasing $P$. thonningii. This could be due to the lower ADF and NDF values of $P$. thonningii which was reflected in the improved ADF and NDF digestibility values of the fed forage.

Table 4: Nutrient digestibility of the feed (\%)

\begin{tabular}{lllll}
\hline & \multicolumn{2}{l}{ Level of Piliostigma thonningii supplementation } & \\
\cline { 2 - 5 } & 0 & 10 & 20 & SEM \\
\hline Crude protein & $26.54^{\mathrm{c}}$ & $46.12^{\mathrm{b}}$ & $62.08^{\mathrm{a}}$ & 7.30 \\
NDF & $58.21^{\mathrm{c}}$ & $63.97^{\mathrm{b}}$ & $71.37^{\mathrm{a}}$ & 5.82 \\
ADF & $56.75^{\mathrm{b}}$ & $59.43^{\mathrm{b}}$ & $68.32^{\mathrm{a}}$ & 4.91 \\
\hline
\end{tabular}

$\mathrm{NDF}=$ Neutral detergent fibre, $\mathrm{ADF}=$ Acid detergent fibre, $\mathrm{SEM}=$ Standard Error of Mean.

$\mathrm{a}, \mathrm{b}, \mathrm{c}$, means values with different superscripts within the same row are significantly different $(\mathrm{P}<0.05)$. 


\section{Jemiseye, Akinlade, Ogunwole and Adedej}

\section{Conclusion}

The study showed that feeding Piliostigma thonningii leaf as supplement to Panicum maximum during dry season encouraged high feed and crude protein intake in West African dwarf goats. Weight gain was increased at $10 \%$ supplemental Piliostigma thonningii while nutrient digestibility was high at 20\% Piliostigma thonningii supplementation. It is suggested that Piliostigma thonningii could be used as supplement with grass to West African dwarf goats up to $10 \%$ due to its high protein contents.

\section{References}

Abdelrahman, M. M., Kincaid, R. L. and Elzubeir, E. A. 1998. Mineral deficiencies in grazing dairy cattle in Kordofan and Darfur Regions in western Sudan. Trop. Anim. Health Prod., 30: 123-135.

Adegbola, A. A. and Onayinka, B. 1996. The Production and Management of Grass/Legume mixture at Agege. Nigerian Agricultural Journal, 3: 84-91.

Akingbade, A. A. Akinlade, A. and Aderinola, O. A. 2006. Leguminous Browse Specie and some Antinutritional Constituents. In: Basic Concept in Pasture Science. Positive press Ibadan Nigeria Pg 38-40.

Aletor, V. A. and Omodara, O. A. 1994. Studies on some leguminous browse plants with particular reference to their proximate, mineral and some endogenous antinutritional constituents. Animal Feed Science Technology, 46 pp.343-348.

AOAC (Association of Official Analytical Chemists). 1990. Official Methods Analysis $15^{\text {th }}$ Edition. AOAC, Inc. Washington DC.
Etela, I. and Suoware, A. E. 2012. Chemical Composition, Dry Matter Intake by West African Dwarf Goats and In Vitro Digestibility of Panicum maximum and Palm Kernel Cake Mixtures. Journal of Agriculture, Forestry and the Social Sciences. 10.4314/joafss.v10i1.26.

Gbolagunte, G. O. and Mshelbwala, A. S. 1991. Concurrent tendency of dermatophilosis with other Skin disease in Nigeria small ruminant and their consequent effect on the physical Quality of the leathers. Paper presented at the $2^{\text {nd }}$ international, symposium on Dermatophilosis, VOM Nigeria. .

Gibbs Russell, G. E., Watson, L., Koekemoer, M., Smook, L., Barker, N. P., Anderson, H. M. and Dallwitz, M. J. 1991. Grasses of Southern Africa. Memoirs of the Botanical Survey of South Africa 58: 10- 11 .

Jimoh, F. O. and Oladeji, A. T. 2005. Preliminary Studies of Piliostigma thonningii seeds.Proximatic analysis, mineral composition and photochemical screening. Afri. J. Biotechnol. 4(12): 1439-1442.

Jiwuba, P. C., Ahamefule, F. O., Okechukwu, O. S. and Ikwunze, K. 2016. Feed intake, body weight changes and haematology of West African dwarf goats fed dietary levels of Moringa oleifera leaf meal. Agricultura 13(1-2), 7177.

Khan, M., Karnpanit, W., Abbas, S., Huma, Z. and Jayasena, V. 2015. Phytochemical composition and bioactivities of lupin: a review. International Journal of Food Science and Technology. Pp: 9.

Merck \& Co. 2008. Inc. Whitehouse Station. NJ USA. 
Oakenfull, D. and Sidhu, G. 1990. Could saponins be a useful treatment for hypercholesterolemia European Journal of Clinical Nutrition, 44, 79-88.

Osagie, A. U. and Eka, O. U. 1998. Nutritional Quality of Plant Foods. Post-Harvest Research Unit, University of Benin, Benin. pp. 34 41.

Parker, B. N. and Blowey, R.W. 1976. Investigations into the relationship of selected blood components to nutrition and fertility of the dairy cows under commercial farm conditions. Vet. Rec., 98: 394-404.

Prakash, D. Nath, P. and Pal, M. 1993. Composition, variation of nutritional contents in leaves, seed protein, fat and fatty acid profile of chenopodium species. Journal of the Science of Food and Agriculture 62(2):203-205.
S.A.S. 1990 SASISTAT User's Guide Statistical Analysis System Institute Inc. Gary, N.C.I.

Sathe, S. K., Salunke, D. K. and Cheryan, M. 1984. Technology of removal of unwanted components of dry beans. Crit. Rev. Food Sci. Nutr., 2: 263-287.

van Rensburg, H. J. 1968. Growth and seasonal composition of natural grassland in Zambia. The Journal of British Grassland Society 23:(1)51-52.

Williamson, G. and Payne, W. J A. 1978. An introduction to animal husbandry in the tropics. Longman, London, UK. pp. 463-483.

Received: $17^{\text {th }}$ May, 2018

Accepted: $19^{\text {th }}$ February, 2019 